\title{
Post-kinematic diorite intrusions in Archaean basement rocks around outer Fiskefjord, southern West Greenland
}

\author{
ADAM A. GARDE
}

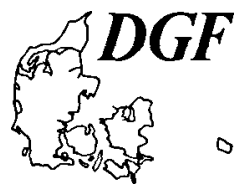

Garde, A. A.: Post-kinematic diorite intrusions in Archaean basement rocks around outer Fiskefjord, southem West Greenland. Bull. geol. Soc. Denmark, Vol. 39, pp. 167-177, Copenhagen, December 20th, 1991. https://doi.org/10.37570/bgsd-1991-39-07

\begin{abstract}
About twenty small dioritic intrusions around outer Fiskefjord, southern West Greenland, which are undeformed and unmigmatised, mark the final stage in middle Archaean accretion of continental crust, deformation and high-grade metamorphism in the Akia terrane. The diorites were emplaced into hot tonalitic gneisses, some of which were thoroughly retrograded from granulite facies prior to diorite intrusion. The diorites are themselves sporadically retrograded. A conventional zircon U-Pb age of 3017 $+12 /-10 \mathrm{Ma}$ has been obtained from one of the diorites. The diorites have $\mathrm{SiO}_{2}$ contents between ca. 52 and $58 \mathrm{wt} . \%$ and up to ca. $15 \% \mathrm{MgO}$, and some of them border on leuconorite or anorthosite, with normative plagioclase contents up to ca. $85 \mathrm{wt}$. \%. Trace element compositions are characterised by elevated amounts of $\mathrm{Zn}, \mathrm{Co}, \mathrm{Ni}$, and especially $\mathrm{Cr}$, but low contents of several LIL elements, and they were probably contaminated with sialic crust. The diorite intrusions may be related to a group of a more mafic intrusions with anomalous contents of precious metals, forming the "norite belt" some $50 \mathrm{~km}$ north of Fiskefjord.
\end{abstract}

A. A. Garde, Geological Survey of Greenland, Oster Voldgade 10, DK-1350 København K. November 23rd, 1990 .

\section{Introduction}

Around the outer part of Fiskefjord in southern West Greenland, about twenty intrusions of Archaean dioritic rocks have been located by the author and M. Marker, University of Copenhagen, during systematic geological mapping for the Geological Survey of Greenland (GGU), see Fig. 1. Berthelsen (1960) made detailed descriptions of a few small post-kinematic diorites on the peninsula of Tovqussap nunâ north of Fiskefjord, and the present report shows that such diorites are not confined to Tovqussap nunâ. The diorite intrusions range from a few $\mathrm{m}^{2}$ to almost one $\mathrm{km}^{2}$ in outcrop size and comprise less than one per cent of the exposed area. They are, however, quite conspicuous in the field because they are completely undeformed, unmigmatised and intrude all other Archaean lithologies, having been intruded after the regional retrogression that affected the granulite facies gneisses in the region (see below).

A conventional $\mathrm{U}-\mathrm{Pb}$ zircon discordia age of $3017+10 /-12$ Ma $(2 \sigma)$ has been obtained from one of the diorites south-east of Tartorssuaq, sample 339512 shown on Fig. 1 (B. T. Hansen, pers. comm., 1990).

The diorites are important because they represent the final stage in the Archaean igneous and tectono-metamorphic evolution of the Fiskefjord area. In the following the diorites and their field relations are described, and major and trace element geochemistry of 13 diorite samples is presented. The diorites are compared with another group of post-kinematic mafic intrusions which crop out some $50 \mathrm{~km}$ north of Fiskefjord, and the origin and mode of emplacement of the diorites are discussed in the context of the geological evolution in the Godthåbsfjord-Fiskefjord region.

\section{Regional setting}

\section{General}

A condensed account of the Archaean evolution in the Fiskefjord area is given here in order to set 


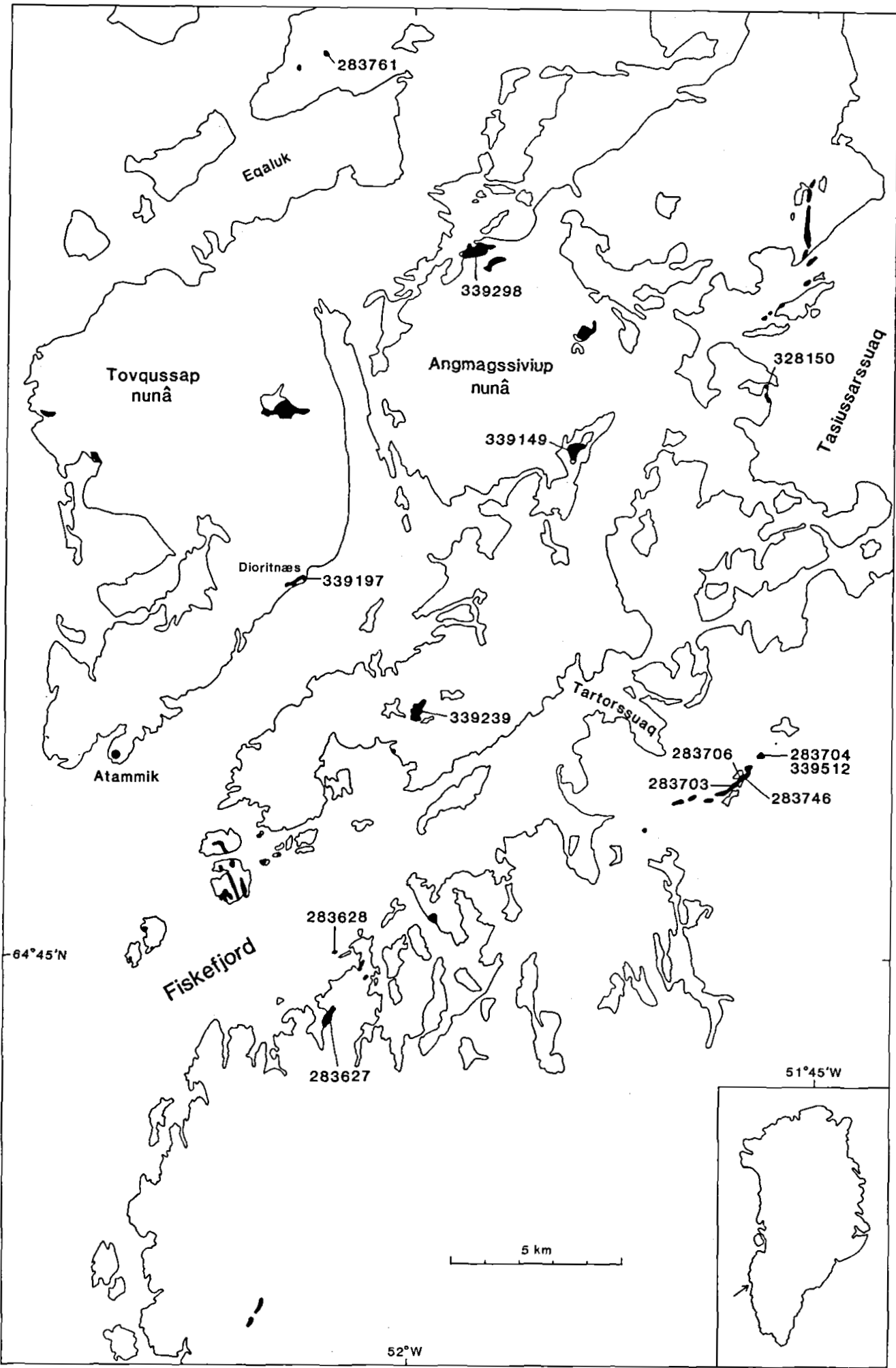

Figure 1. Outcrops of post-kinematic diorites around outer Fiskefjord, with sample localities. 
the geological scene of the post-kinematic diorites.

A detailed account was presented by the author at the Steno medal award meeting of the Danish Geological Society in November 1989 and has been published elsewhere (Garde 1990).

The Fiskefjord area is part of the ca. $3000 \mathrm{Ma}$ Akia tectono-stratigraphic terrane (Nutman et al. 1989) of the Godthåbsfjord area (McGregor et al. 1991 - this volume). The Akia terrane was juxtaposed at ca. $2700 \mathrm{Ma}$ against the more southerly Akulleq terrane in central Godthåbsfjord, which contains the early Archaean amphibolite-facies Amîtsoq gneisses and late Archaean Ikkattoq gneisses. Substantial parts of the terranes in the Archaean craton north and south of central Godthåbsfjord consist of either hornblende-granulite facies rocks or retrograded equivalent rocks with secondary amphibolite facies mineralogy.

\section{The Fiskefjord area}

The geological map sheet 64 V.1 Fiskefjord in scale 1:100 000 (Garde 1989) shows structures, lithologies and the metamorphic facies distribution in the Fiskefjord area. The area consists of middle Archaean orthogneisses, most of which were subjected to granulite facies metamorphism at ca. $3000 \mathrm{Ma}$ and retrograded under declining amphibolite facies P-T conditions shortly afterwards. They enclose screens and enclaves of older supracrustal pyribolites (ortho- and clinopyroxene-bearing amphibolites, see Berthelsen 1960) and subordinate ultrabasic rocks and metasedimentary biotite (-garnet-sillimanite) schists.

The granulite facies gneisses in the south-western part of the Fiskefjord area consist of dark, crumbling, polyphase dioritic, tonalitic and trondhjemitic (opx $\pm \mathrm{cpx} \pm \mathrm{hbl} \pm \mathrm{bt}-\mathrm{plag} \pm \mathrm{qtz}$ ) orthogneisses with granular, medium-grained, equilibrium metamorphic textures and more or less evenly distributed mafic minerals. The granulites commonly contain an irregular network of centimetre-thick quartz-plagioclase veins which indicate partial anatexis (Garde 1990). They grade into pale, recrystallised and retrograded gneisses with centimetre-sized patches of secondary bluish-green actinolitic amphibole (low in $\mathrm{Na}$, $\mathrm{K}, \mathrm{Ti}$ and $\mathrm{Al}$ ) and radiating sheaves of $\mathrm{Ti}$-poor secondary biotite. The retrograded gneisses can hardly be recognised as polyphase gneisses because all lithological contacts are blurred by the recrystallisation. Retrogression has also taken place along narrow linear belts of assumed Archaean age associated with localised deformation, and adjacent to Proterozoic faults. To the east the retrograded gneisses give way to unretrograded amphibolite facies gneisses which have never been subject to granulite facies metamorphism. These gneisses have preserved sharp igneous contacts between adjacent phases in spite of deformation and amphibolite facies metamorphism. The amphibolite facies polyphase gneisses have subhedral medium-grained biotite (and/or hornblende) grains evenly distributed throughout the rock.

The gneisses in the Fiskefjord area contain local sheets of younger granites, some of which are mesoperthite-bearing and were intruded under granulite facies conditions. Other lower-temperature (two-feldspar) granites (including the Qugssuk granite, see below) occur in the retrograde gneisses and may cut a diffuse gneiss foliation delineated by biotite and amphibole formed during retrogression. These granites are accordingly believed to postdate retrogression of the gneisses. Two large tonalitic plutons, to the north-east the Taserssuaq tonalite, and to the north the Finnefjeld gneiss, both of which are ca. $1000-1500 \mathrm{~km}^{2}$ in outcrop size, were also formed late in the evolution of the area; intrusion of the Finnefjeld gneiss postdates the retrogression.

Gneisses and granites in the Fiskefjord area have given ages around $3000 \mathrm{Ma}$ by whole-rock $\mathrm{Pb}-\mathrm{Pb}$ and $\mathrm{Rb}-\mathrm{Sr}$, and zircon U-Pb methods (see Garde 1990 for details). The radiometric data indicate that both $\mathrm{Rb}$ and $\mathrm{Pb}$ were highly mobile during the granulite facies metamorphism and retrogression and suggest that the widespread retrogression happened shortly after the metamorphic maximum at ca. $3000 \mathrm{Ma}$.

\section{Element mobility during metamorphism}

Elements like $\mathrm{Al}, \mathrm{Ti}, \mathrm{Zr}, \mathrm{Nb}, \mathrm{Y}$, and REE have similar distributions in the amphibolite facies, granulite facies, and retrograded gneisses, which supports field evidence that the three groups of gneisses belong to the same comagmatic series, in part superimposed by granulite facies metamorphism and retrogression. $\mathrm{Na}, \mathrm{K}, \mathrm{Rb}, \mathrm{Pb}$, and $\mathrm{Th}$ 
occur in very low concentrations in the granulite facies gneisses, whereas the retrograded gneisses have concentrations of these elements which are intermediate between those in granulite facies and in un-retrograded amphibolite facies. The observed distribution patterns of mobile elements were interpreted by Garde (1990) to have been caused by the granulite facies metamorphism and retrogression, rather than being primary igneous features.

Mechanisms of granulite facies metamorphism and retrogression in the Fiskefjord area

Garde (1990) discussed the metamorphic evolution in the Fiskefjord area in terms of three general models of granulite facies metamorphism: metamorphism of already dry rocks; dehydration by $\mathrm{CO}_{2}$; and dehydration by removal of aqueous fluid in anatectic melts. The first model was discounted primarily because of field relations, geochemistry, and the geological setting of the Fiskefjord area in a typical bimodal orthogneissamphibolite terrain. Garde (1990) also pointed out that there are many differences between the Greenlandic granulites and those in, for example, South India. Some granulites in South India are believed to have been formed by the second mechanism, $\mathrm{CO}_{2}$ flushing (e.g. Janardhan et al. 1982). Contrary to the common prograde amphibolite to granulite facies transitional areas in South India, the granulites in southern West Greenland are normally surrounded by large tracts of rocks which were retrograded to amphibolite facies under static conditions - a prograde amphibolite to granulite facies transition zone has so far only been identified at the head of Bjørnesund about $200 \mathrm{~km}$ south-south-east of the Fiskefjord area (Friend 1989). Besides, the granulites in southern West Greenland have distinctly depleted geochemical compositions, charnockitic rocks sensu stricto are almost absent, and in the Fiskefjord area where fluid inclusions have been studied (Garde 1990) $\mathrm{CO}_{2}$-rich inclusions are small and rare. There is also common evidence of partial anatexis within the Fiskefjord granulites.

Garde (1990) argued that the granulite facies metamorphism in the Fiskefjord area was thermally induced and involved dehydration melting, and suggested an evolution of the gneiss terrane which can be summarised as follows. The voluminous ca. $3000 \mathrm{Ma}$ old gneisses were successively emplaced (first as sheets intruding into each other and then as diapirs), deformed, metamorphosed and partially retrograded within a short time interval. As shown by Wells $(1979,1980)$ short-lived granulite facies $\mathrm{P}, \mathrm{T}$ conditions may be reached in the lower part of tonalitic rocks intruded into each other, if the rate of intrusion is high enough and the volumes of magma are large. During the later stages of continental crustal accretion in the Fiskefjord area, partial anatexis took place at increasing depths, producing first granitic and later trondhjemitic melts. The melts absorbed aqueous fluid and LIL elements and moved upwards, leaving progressively more dehydrated and geochemically depleted rocks behind. Garde (1990) concluded that the extensive retrogression, recrystallisation and metasomatism took place in previously partially dehydrated rocks when the remobilised leucocratic melts solidified and liberated most of their $\mathrm{H}_{2} \mathrm{O}$ content.

\section{The post-kinematic diorites}

\section{Distribution and field relations}

Figure 1 shows the occurrences of post-kinematic diorites around outer Fiskefjord. In addition to those shown on Fig. 1, two small post-kinematic diorites occur $5.5 \mathrm{~km}$ north of Qugssuk and ca. 17 $\mathrm{km}$ north-east of the head of Fiskefjord (see the geological maps, Garde 1987, 1989). The first mentioned of these diorites has intruded the boundary between supracrustal amphibolites and the Qugssuk granite, which has previously been dated at $2969 \pm 32 \mathrm{Ma}$ (Garde et al. 1986). This relation provides a maximum age of the diorites. The intrusions are irregular plugs measuring up to ca. $0.5 \times 1 \mathrm{~km}$ (e.g. on Angmagssiviup nunâ), elongated, sometimes curved, up to 1-2 km long dyke-like bodies (e.g. west of Tasiussarssuaq, on Tovqussap nunâ, and on the islands south-east of Atammik), and inclined sheets of similar dimensions (south-east of Tartorssuaq), see Fig. 2. Often several exposures occur in groups, suggesting a common source at depth. The diorites tend to be elongated north-east to south-west. Their boundaries are discordant to regional structure 


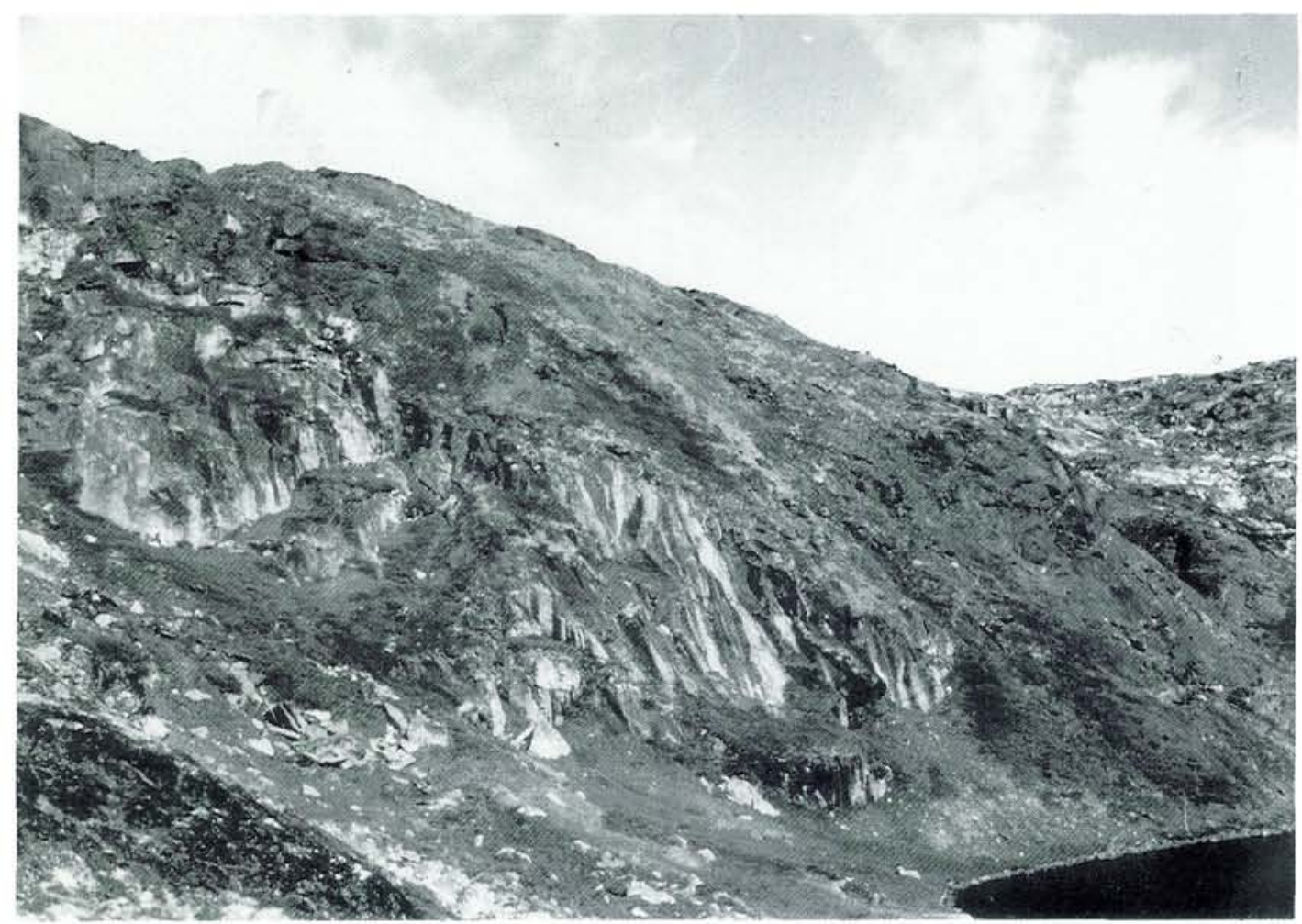

Figure 2. Inclined sheet of post-kinematic diorite (the dark ridge, dipping towards the lake) in white retrograded tonalitic gneiss. The diorite sheet is ca. $100 \mathrm{~m}$ thick. South-east of Tartorssuaq.

and lithological boundaries, with some exceptions where diorites have been emplaced along the boundaries between orthogneisses and mafic supracrustal rocks.

The contacts between the diorites and host rocks are sharp when viewed from a distance (Fig. 2), but the margins of larger diorites against quartzo-feldspathic orthogneisses are gradational over ca. 2-5 metres. The marginal zones consist of massive rocks intermediate in composition between diorite and gneiss. These observations suggest that the host rocks were hot when the diorites were emplaced. Near such margins the diorites often enclose rounded, coarse-grained, up to $\mathrm{ca} .10 \mathrm{~cm}$ large quartzo-feldspathic xenoliths, presumably remnants of host rock gneiss. Diorite-pyribolite contacts are easier to delineate since hybrid marginal zones do not occur. Pyribolite xenoliths are common and have centimetrethick reaction rims. Berthelsen (1960) presented evidence that some of the pyribolite inclusions within a diorite on Tovqussap nunâ had retained their original orientations, which suggested to him that the diorite replaced the pyribolites.

The post-kinematic diorites around outer Fiskefjord are medium- to coarse- grained, dark grey to dull brown in colour and the exposures are typically weathered with rounded, homogeneous, crumbling outcrop surfaces. Sometimes they contain a faint mineral layering but generally they are very uniform and unfoliated, in contrast to some of their host rocks. They completely lack signs of migmatisation and most of them are not cut by pegmatites, unlike their host rocks. Only two observations were made of diorite cut by a single ca. $5 \mathrm{~cm}$ thick, planar pegmatite sheet with sharp margins to the diorite.

Textures in the diorites are very variable and in part reflect their highly variable mineralogical composition. Although most of the diorite outcrops are homogeneous, there are commonly large compositional and textural variations within the larger diorite bodies, for instance in the largest diorite sheet south-east of Tartorssuaq. 


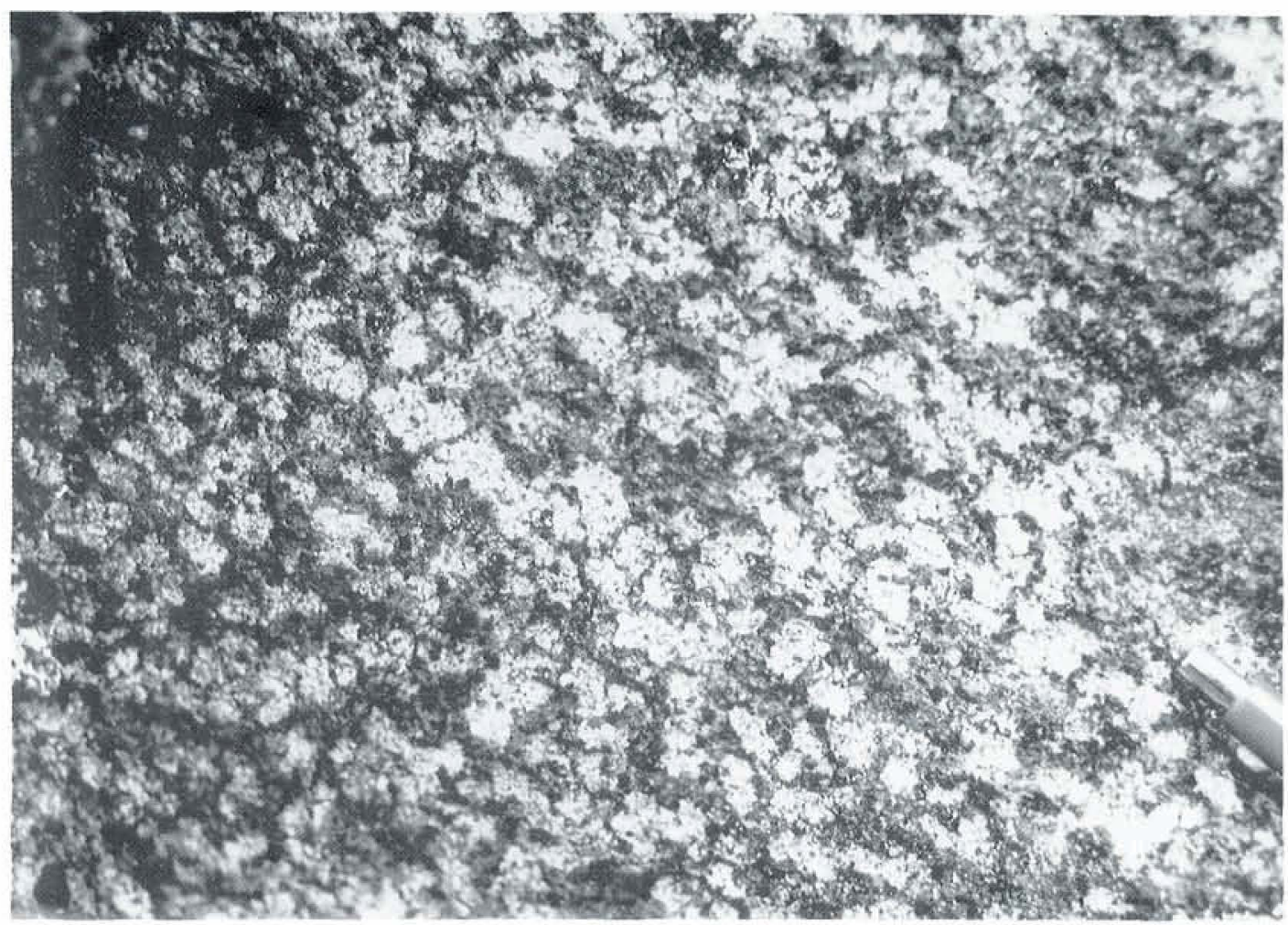

Figure 3. Post-kinematic diorite north of Eqaluk, composed of ca. 1-2 cm large plagioclase aggregates with interstitial orthopyroxene, hornblende and biotite.

These variations could not be related in a systematic way to the external shapes of the intrusions.

Those post-kinematic diorites which occur in granulite facies and retrograded gneisses, are composed of intermediate plagioclase and highly variable proportions of hypersthene, diopsidic clinopyroxene, hornblende, and sometimes coarse flakes of biotite. The two diorites found farther east (north of Qugssuk and north-east of the head of Fiskefjord), which were emplaced at slightly higher crustal levels into un-retrograded granitic and granodioritic rocks, contain plagioclase, biotite, and poikilitic hornblende with clinopyroxene inclusions and rims of blue-green hornblende.

The majority of the diorites are characterised by closely spaced, ca. $0.5-0.8 \mathrm{~cm}$ large, equidimensional, poikilitic hornblende crystals with pyroxene and plagioclase inclusions, set in a medium-grained plagioclase matrix. Other exposures mainly display coarse-grained plagioclase with a granular texture, or are composed of medium-grained plagioclase with evenly distributed,
1-3 cm large, sub- to euhedral pyroxene and hornblende grains. Still others contain coarse plates of randomly orientated biotite and subhedral hornblende surrounded by plagioclase. A few of the outcrops display closely packed medium- to coarse-grained poikilitic hornblende and subhedral clino- and orthopyroxene crystals with less than ca. 20 per cent interstitial plagioclase.

A very conspicuous type of diorite from outer Fiskefjord is composed of ellipsoidal plagioclase aggregates up to ca. $3 \mathrm{~cm}$ across with interstitial pyroxene and hornblende, and resemble protoorbicules as defined by Leveson (1966). This texture is also developed in the two diorites north of Eqaluk (Fig. 3), north of Tasiussarssuaq, and south-east of Tartorssuaq. Single-shelled orbicular diorite occurs locally within the diorites at Dioritnæs on eastern Tovqussap nunâ and was described in detail by Berthelsen (1960). The orbicular diorite at Dioritnæs contains ellipsoid aggregates several centimetres across, composed of single (and rarely several concentric) shells of plagioclase $\left(\mathrm{An}_{40}\right)$ and radially arranged, elon- 
Table 1. Major and trace element compositions of 13 post-kinematic diorites from the Fiskefjord area. Localities of 12 samples are shown on Fig. 1; sample 278884 is located at $65^{\circ} 08^{\prime} \mathrm{N}, 50^{\circ} 00^{\prime} \mathrm{W}$, north-east of inner Fiskefjord. Major and trace elements were analysed by standard XRF methods at GGU and at the Geological Central Institute, University of Copenhagen, respectively. The CIPW norms are based on recalculations to $100 \mathrm{wt}$. \% (volatile-free) and adjustment of oxidation ratios to $\mathrm{Fe}_{2} \mathrm{O}_{3} / \mathrm{FeO}=0.15$. Also the samples 283628 , 283703, 283704 and 283761 become quartz-normative if the observed higher oxidation ratios are retained in the norm calculations.

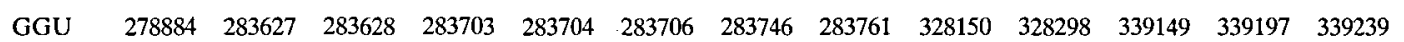
No.

\begin{tabular}{|c|c|c|c|c|c|c|c|c|c|c|c|c|c|}
\hline $\mathrm{SiO}_{2}$ & 57.86 & 57.07 & 55.23 & 53.34 & 53.69 & 53.73 & 53.25 & 54.08 & 52.27 & 53.55 & 52.61 & 52.62 & 53.87 \\
\hline $\mathrm{TiO}_{2}$ & 0.44 & 0.07 & 0.09 & 0.58 & 1.38 & 0.44 & 0.29 & 0.72 & 0.39 & 0.18 & 0.22 & 0.32 & 0.41 \\
\hline $\mathrm{Al}_{2} \mathrm{O}_{3}$ & 10.85 & 23.51 & 21.63 & 9.14 & 19.22 & 17.81 & 16.34 & 13.17 & 6.71 & 20.09 & 19.03 & 10.91 & 22.96 \\
\hline $\mathrm{Fe}_{2} \mathrm{O}_{3}$ & 2.85 & 0.55 & 0.66 & 3.31 & 3.59 & 2.20 & 1.85 & 2.90 & 2.01 & 1.01 & 1.33 & 5.41 & 1.05 \\
\hline $\mathrm{FeO}$ & 5.71 & 2.16 & 2.96 & 6.20 & 3.68 & 4.23 & 4.57 & 8.48 & 7.38 & 3.60 & 4.17 & 10.30 & 2.29 \\
\hline $\mathrm{MnO}$ & 0.18 & 0.06 & 0.08 & 0.17 & 0.09 & 0.11 & 0.13 & 0.21 & 0.19 & 0.09 & 0.10 & 0.29 & 0.04 \\
\hline $\mathrm{MgO}$ & 8.66 & 2.37 & 4.49 & 13.09 & 3.68 & 6.87 & 7.92 & 10.56 & 15.49 & 6.66 & 6.10 & 11.72 & 2.86 \\
\hline $\mathrm{CaO}$ & 7.60 & 7.37 & 8.35 & 10.23 & 7.13 & 8.91 & 9.78 & 3.83 & 11.62 & 9.57 & 9.66 & 3.78 & 9.42 \\
\hline $\mathrm{Na}_{2} \mathrm{O}$ & 2.79 & 5.60 & 4.85 & 2.21 & 4.98 & 4.09 & 3.61 & 3.04 & 1.59 & 3.35 & 3.80 & 3.58 & 4.56 \\
\hline $\mathrm{K}_{2} \mathrm{O}$ & 0.98 & 0.25 & 0.35 & 0.75 & 0.80 & 0.50 & 0.42 & 1.69 & 0.20 & 0.28 & 0.36 & 0.45 & 0.41 \\
\hline $\mathrm{P}_{2} \mathrm{O}_{5}$ & 0.08 & 0.05 & 0.06 & 0.13 & 0.56 & 0.12 & 0.12 & 0.34 & 0.10 & 0.06 & 0.08 & 0.45 & 0.06 \\
\hline LoI & 1.53 & 0.68 & 1.23 & 1.85 & 0.79 & 1.13 & 1.52 & 0.96 & 1.51 & 0.85 & 2.26 & 0.84 & 1.36 \\
\hline Sum & 99.53 & 99.74 & 99.97 & 101.00 & 99.59 & 100.14 & 99.79 & 99.98 & 99.46 & 99.28 & 99.71 & 100.67 & 99.28 \\
\hline Rb & 17 & $<1$ & 1 & 14 & 3 & 4 & 2 & 76 & 1 & 1 & 2 & 4 & 2 \\
\hline $\mathrm{Ba}$ & 451 & 188 & 375 & 667 & 415 & 270 & 238 & 893 & 145 & 141 & 164 & 358 & 122 \\
\hline $\mathrm{Pb}$ & 8 & 9 & 7 & 5 & 8 & 12 & 7 & 7 & 5 & 7 & 3 & 4 & 5 \\
\hline $\mathrm{Sr}$ & 276 & 1060 & 1077 & 417 & 974 & 857 & 838 & 482 & 202 & 789 & 784 & 417 & 645 \\
\hline La & 27 & 1 & 10 & 31 & 28 & 14 & 10 & 18 & 10 & 7 & 5 & 24 & 5 \\
\hline $\mathrm{Ce}$ & 48 & 6 & 22 & 90 & 54 & 27 & 29 & 50 & 22 & 15 & 14 & 38 & 9 \\
\hline $\mathrm{Nd}$ & 34 & 3 & 10 & 60 & 24 & 21 & 17 & 28 & 13 & 8 & 7 & 20 & 6 \\
\hline$Y$ & 24 & $<1$ & 3 & 22 & 7 & 8 & 6 & 9 & 10 & 4 & 4 & 7 & 6 \\
\hline Th & $<1$ & 4 & 4 & $<1$ & 1 & 4 & $<1$ & 1 & 4 & 3 & $<1$ & 1 & 2 \\
\hline $\mathrm{Zr}$ & 66 & 6 & 7 & 75 & 10 & 27 & 25 & 3 & 39 & 10 & $<1$ & $<1$ & 5 \\
\hline $\mathrm{Nb}$ & 4.7 & 0.7 & $<0.5$ & 2.4 & 3.5 & 1.5 & 2.0 & 3.4 & 1.4 & 0.7 & 1.4 & 1.9 & 2.4 \\
\hline $\mathrm{Zn}$ & 147 & 57 & 51 & 152 & 68 & 89 & 91 & 283 & 100 & 52 & 56 & 374 & 43 \\
\hline $\mathrm{Cu}$ & 49 & 20 & 22 & 101 & 45 & 78 & 97 & $<1$ & 85 & 87 & 19 & 7 & 19 \\
\hline Co & 64 & 42 & 37 & 64 & 38 & 47 & 51 & 69 & 81 & 40 & 45 & 70 & 35 \\
\hline $\mathrm{Ni}$ & 239 & 33 & 77 & 486 & 29 & 144 & 195 & 227 & 483 & 157 & 67 & 189 & 42 \\
\hline V & 112 & 19 & 44 & 186 & 196 & 116 & 99 & 121 & 176 & 61 & 81 & 206 & 89 \\
\hline $\mathrm{Cr}$ & 390 & 47 & 77 & 1130 & 14 & 154 & 258 & 916 & 1610 & 343 & 50 & 3380 & 36 \\
\hline $\mathrm{Ga}$ & 16 & 23 & 18 & 16 & 21 & 17 & 16 & 20 & 13 & 18 & 18 & 20 & 22 \\
\hline $\mathrm{Sc}$ & n.d. & 4 & 10 & 45 & 16 & 25 & 26 & 21 & 49 & 16 & 20 & 24 & 13 \\
\hline $\mathbf{Q}$ & 8.57 & 2.57 & & & & & & & & 1.49 & & & 0.74 \\
\hline or & 5.92 & 1.43 & 2.04 & 4.48 & 4.80 & 2.93 & 2.47 & 10.10 & 1.21 & 1.62 & 2.18 & 2.67 & 2.48 \\
\hline$a b$ & 24.14 & 47.86 & 41.58 & 18.91 & 42.77 & 35.01 & 31.12 & 26.02 & 13.75 & 28.82 & 33.02 & 30.45 & 39.44 \\
\hline an & 14.51 & 36.67 & 36.72 & 12.92 & 28.14 & 29.12 & 27.68 & 16.97 & 10.81 & 39.63 & 34.69 & 12.43 & 41.87 \\
\hline $\mathrm{di}$ & 19.10 & & 3.98 & 30.27 & 3.39 & 11.95 & 16.98 & & 38.11 & 6.68 & 11.30 & 2.84 & 4.47 \\
\hline hy & 25.10 & 9.99 & 14.39 & 26.43 & 14.29 & 13.86 & 15.75 & 41.54 & 29.11 & 20.43 & 14.17 & 36.28 & 9.45 \\
\hline ol & & & 0.33 & 3.82 & 1.31 & 4.80 & 3.96 & 0.85 & 4.25 & & 2.96 & 10.74 & \\
\hline $\mathrm{mt}$ & 1.62 & 0.51 & 0.69 & 1.78 & 1.34 & 1.20 & 1.22 & 2.15 & 1.80 & 0.88 & 1.06 & 2.92 & 0.63 \\
\hline il & 0.85 & 0.13 & 0.17 & 1.11 & 2.66 & 0.85 & 0.56 & 1.38 & 0.76 & 0.35 & 0.43 & 0.61 & 0.80 \\
\hline ap & 0.19 & 0.09 & 0.12 & 0.28 & 1.29 & 0.28 & 0.26 & 0.80 & 0.21 & 0.12 & 0.19 & 1.05 & 0.14 \\
\hline C & & 0.74 & & & & & & 0.19 & & & & & \\
\hline
\end{tabular}

gated grains of orthopyroxene and hornblende, which surround a granular core with similar mineralogical composition. The matrix to the orbicules is dioritic with plagioclase $\left(\mathrm{An}_{35}\right)$, amphibole and biotite (Berthelsen 1960).

Both those post-kinematic diorites that occur in granulite facies gneisses (south of the mouth of Fiskefjord), as well as those in pale-coloured, recrystallised and completely retrograded gneisses, have retained magmatic textures and have dull brownish weathering colours characteristic of rocks with orthopyroxene-bearing parageneses. Field evidence therefore very strongly suggests that the emplacement of the post-kinematic diorites must have postdated most of the widespread high-grade retrogression in the Fiskefjord area.

The observed mineralogy of the post-kinematic diorites is a combination of primary phases and products of (auto-?) metamorphic reactions. The 

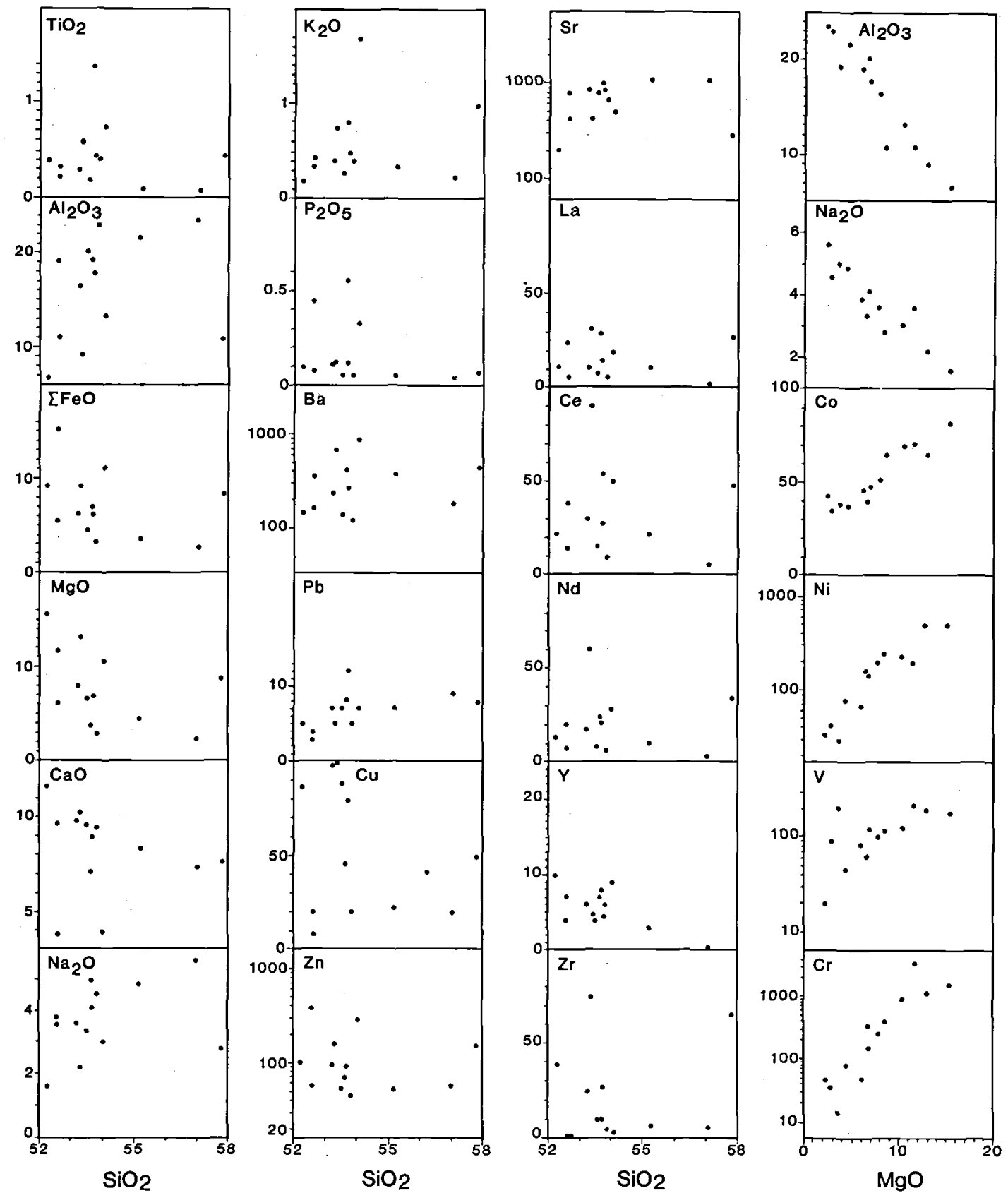

Figure 4. Variation diagrams of major elements (wt. \%) and trace elements (ppm) against $\mathrm{SiO}_{2}$ (wt. \%), three columns, and against $\mathrm{MgO}$ (wt. \%), right column.

large rounded inclusions of ortho- and clinopyroxene sometimes found in the poikilitic hornblende indicate that the latter mineral grew at the expense of earlier pyroxenes, either during latestage crystallisation of the diorite magma or as an effect of (auto-?) retrogression. The poikilitic hornblende may in turn be overgrown by $1-2 \mathrm{~mm}$ thick rims of homogeneous blue-green amphibole, as seen in some samples of the ca. $2 \mathrm{~km}$ long diorite sheet south-east of Tartorssuaq. It should be noted that this late amphibole does not resemble the spongy and zoned blue-green amphi- 
bole with quartz inclusions, which is characteristic of the regionally retrograde gneisses, and which is commonly associated with radiating sheaves of biotite in the latter rocks. It is open to discussion whether the local growth of blue-green amphibole is due to auto-metasomatism of the diorites during their emplacement into already retrograded gneisses and (amphibolite facies) granitic rocks, or if it is due to a late stage in the regional retrogression as suggested by Berthelsen (1960) for diorites on Tovqussap nunâ.

Partial deuteric alteration of ortho- and clinopyroxene to very fine-grained aggregates, presumably of epidote, amphibole, chlorite and oxides, is occasionally observed.

\section{Geochemistry}

Twelve chemical analyses of post-kinematic diorites from the area around outer Fiskefjord and one analysis from the diorite north-east of Fiskefjord are presented in Table 1. The diorites have very variable modal compositions and accordingly large variations in their major element oxide concentrations, especially $\mathrm{Al}_{2} \mathrm{O}_{3}, \mathrm{MgO}$, and $\mathrm{CaO}$, but a restricted range of $\mathrm{SiO}_{2}$ (from ca. 52.5 to $58 \mathrm{wt} . \%)$. Several diorites have high $\mathrm{MgO}$ contents of $>10 \mathrm{wt}$. $\%$ and are further characterised by low $\mathrm{TiO}_{2}$ and $\mathrm{K}_{2} \mathrm{O}$, and variable $\mathrm{P}_{2} \mathrm{O}_{5}$. The diorites have low contents of several incompatible trace elements (e.g. $\mathrm{Rb}, \mathrm{La}, \mathrm{Y}, \mathrm{Th}, \mathrm{Zr}$, and $\mathrm{Nb}$ ), but have elevated contents of $\mathrm{Zn}, \mathrm{Co}$, $\mathrm{Ni}$, and especially $\mathrm{Cr}$.

Figure 4 shows variation diagrams of major and trace elements against $\mathrm{SiO}_{2}$ and $\mathrm{MgO}$. There is a clear positive correlation between $\mathrm{MgO}$ and several transition metals, particularly $\mathrm{Ni}, \mathrm{Co}$ and $\mathrm{Cr}$, and negative correlations between $\mathrm{MgO}$ and $\mathrm{Al}_{2} \mathrm{O}_{3}, \mathrm{Na}_{2} \mathrm{O}$ and $\mathrm{Sr}$ (not shown). Most other diagrams do not show any clear correlation.

\section{Discussion}

Some of the larger diorite bodies display large variations in mineralogical composition, as also shown by the CIPW norms of the analysed diorites (Table 1). These variations also control the trace element geochemistry. The strong positive correlations between $\mathrm{MgO}$ and $\mathrm{Ni}, \mathrm{Co}$ and $\mathrm{Cr}$ are probably caused by their mutual occurrence in orthopyroxene. Likewise, the strong negative correlations between $\mathrm{MgO}$ and $\mathrm{Al}_{2} \mathrm{O}_{3}, \mathrm{Na}_{2} \mathrm{O}$ and $\mathrm{Sr}$ probably reflect that the latter three components are largely confined to plagioclase.

The geochemical data do not suggest that the diorites were formed from comagmatic liquids related to each other by crystal fractionation or anatexis at their source, and there is only scanty field evidence (such as igneous layering) to support that they are local cumulates. Emplacement as crystal mushes with large amounts of cumulus material is another possibility, which is perhaps supported by the mineralogical variations within some of the larger diorite bodies just mentioned, which have no obvious relation to internal structures or their positions in the intrusions.

A third possibility is an origin as deep-seated ultramafic magma which was contaminated by interaction with sialic crust, leading to a superheated dioritic magma. Superheating might take place if a hot mafic or ultrabasic magma engulfed a more felsic magma, or if water was injected into such a magma and felsic wall rock was assimilated (e.g. Vernon 1985).

Field observations and geochemistry seem to suggest this possibility. It has been noted above that 1) the diorites generally have high contents of $\mathrm{MgO}$ and trace elements normally associated with ultrabasic rocks, and that 2) many of the diorites show signs of hydrous corona growth and auto-retrogression. The presence of orbicules in some of the diorites may support growth from a superheated magma, since superheating is an effective way of reducing the number of nuclei in the magma and may lead to growth of orbicules as suggested by Vernon (1985). In favour of superheating is also the strong wall rock alteration associated with the larger diorites, and the observed partially digested gneiss xenoliths. These features also testify to crustal contamination. Analyses of the most plagioclase-rich diorites show that they strongly resemble anorthosite or leuconorite, and they compare well with analyses in Wiebe $(1979$, p. 403) of anorthosite dykes from the Nain complex in Labrador. In this context it can be noted that Wiebe $(1979,1990)$ suggested that these dykes represent unusually feldspathic liquids with compositions well above a plagio- 
clase-clinopyroxene cotectic, and which were not intruded as crystal mushes.

Comparison with noritic rocks of presumed Archaean age north of the Fiskefjord area

The post-kinematic diorites in the Fiskefjord area may be compared with a group of noritic intrusions that occurs in a curved belt along the eastern side of the Finnefjeld gneiss complex some $50 \mathrm{~km}$ north of Fiskefjord. These intrusions are up to about $8 \mathrm{~km}^{2}$ in outcrop size and mainly. consist of orthopyroxene and plagioclase with subordinate clinopyroxene, hornblende and biotite. They were investigated by Kryolitselskabet Øresund A/S around 1970 (Nielsen 1976) and by Secher (1983), because of several Ni-Cu sulphide occurrences within them. Recent unpublished GGU analyses have revealed that some of the mineralisations also contain elevated amounts of precious metals.

These noritic rocks show many similarities with the post-kinematic diorites described in this paper. In a brief description of the noritic rocks and their nickel-copper sulphide mineralisation, Secher (1983) noted their characteristic crumbling appearance and preservation of igneous textures (similar to the post-kinematic diorites). One of the norites locally displays distinct rythmic igneous layering (Fig. 9 in Secher 1983). Boulders of noritic rocks with orbicular texture (as in some of the post-kinematic diorites) were found in the northern part of the norite belt, and Secher (1983) mentioned that some norites locally grade into more plagioclase-rich rocks (like the post-kinematic diorites around outer Fiskefjord). All these features are compatible with the origin suggested above for the post-kinematic diorites from a contaminated, superheated magma with an ultrabasic component. Secher (1983) suggested a syn- to late tectonic emplacement, but did not describe the contact relations between norites and their host rocks in any detail. He mentioned that the norites are cut by several fault zones presumably of both Proterozoic and Palaeozoic age. An examination of some of the samples collected by K. Secher confirmed a textural similarity with post-kinematic diorites; however several of the noritic samples are more strongly retrograded than those around outer Fis- kefjord, and may almost completely consist of retrograde blue-green amphibole-plagioclase aggregates. Further work in the norite belt is required in order to confirm that the post-kinematic diorites around outer Fiskefjord and the norites to the north are indeed related.

\section{Conclusions}

The post-kinematic diorites in the Fiskefjord area, dated at $3017+10 /-12 \mathrm{Ma}$, represent the final stage in Archaean magmatic and high-grade metamorphic activity in the Akia terrane. The age and field relations of the diorites support the conclusion by Garde (1990) that widespread static high-grade retrogression in the Fiskefjord area took place very shortly after granulite facies metamorphism; the erratic partial retrogression of the diorites may have occurred both during and after their emplacement. It can further be concluded that subsequent juxtaposition of the Akia and Akulleq terranes at ca. $2700 \mathrm{Ma}$ did not have strong deformational or thermal effects inside the Akia terrane. The reasons for the renewed magmatic activity in the final stage of the middle Archaean accretion of continental crust, displayed by the post-tectonic diorites in the Fiskefjord area (and perhaps the norites farther north), remain speculative, as does their source. The geochemistry of the diorites, however, shows that they contain a significant ultrabasic component and that their source is likely to have been depleted in some trace elements. The orbicular textures and other evidence may suggest superheated magmas, which could have resulted from assimilation of sialic continental crust by originally ultramafic liquids. It is likely that substantial contamination occurred in the middle continental crust. The observed chemistry of the diorites, with the combination of high $\mathrm{MgO}$ and relatively high $\mathrm{SiO}_{2}$ contents, is unlikely to be a primary feature.

Acknowledgements. T. C. R. Pulvertaft, Geological Survey of Greenland, is thanked for his excellent and enthusiastic organisation of the Steno medal award meeting. The author is grateful to J. Bailey, University of Copenhagen, for trace element analyses, to B. T. Hansen, Universität Münster, for zircon dating, to M. Marker, University of Copenhagen, for contributing to the field work, to T. F. D. Nielsen and F. Kalsbeek, Geological Survey of Greenland, for discussions and comments, and to C. R. L. Friend, Oxford Polytechnic and R. C. 
Newton, University of Chicago, for reviews. This paper is published with the approval of the Geological Survey of Greenland.

\section{Dansk sammendrag}

Omkring tyve smâ Arkæiske dioritiske intrusiver omkring den ydre del af Fiskefjord i det sydlige Vestgrønland har hverken været udsat for deformation eller migmatisering. Intrusionen af disse dioriter markerer afslutningen på midt-Arkæisk kontinental skorpedannelse, deformation, og amfibolit- til granulitfacies metamorfose i 'Akia terrane'. De omgivende tonalitiske orthognejser var varme, da dioriterne blev intruderet, men i nogle områder allerede totalt retrograderet fra granulitfacies. Dioriterne selv har været udsat for sporadisk retrogradering. En af dioriterne er dateret til $3017+12 /-10$ mill. år ved konventionel $\mathrm{U}-\mathrm{Pb}$ zirkon aldersbestemmelse. Dioriterne indeholder mellem ca. 52 og 58 vægt \% SiO $\mathrm{Sg}_{2}$ op til ca. $15 \% \mathrm{MgO}$, og nogle af dem minder i sammensætning om leuconorit eller anorthosit, med normative indhold af plagioklas på op til ca. $85 \%$. Deres indhold af sporelementer er karakteriseret af høje $\mathrm{Zn}-, \mathrm{Co}-, \mathrm{Ni}-$ og især $\mathrm{Cr}$-værdier, og lave vardier for flere LILK ('large-ion lithophile') elementer, og dioriterne er formentlig kontamineret med kontinental skorpe.

Dioritintrusionerne er måske beslægtet med en gruppe st $ø$ rre og mere mafiske intrusioner, 'norit-bæltet', som findes $i$ et område ca. $50 \mathrm{~km}$ nord for Fiskefjord og har anomale, forh $\varphi \mathrm{j}$ ede indhold af ædelmetaller.

\section{References}

Berthelsen, A. 1960: Structural studies in the pre-Cambrian of western Greenland; part II: Geology of Tovqussap nunâ. Bull. Grønlands geol. Unders. 25 (Also Meddr Grønland 123,1) 123 pp.

Friend, C. R. L. 1989: Morphology of granulite-amphibolite facies transitions: The importance of fluid movements. In Bridgwater, D. (ed.) Fluid movements - element transport, and the composition of the deep crust, 19-28. Dordrecht: Kluwer.

Garde, A. A. (compiler) 1987: Geological map of Greenland
1:100000, 65 V.2 S., Isukasia. Copenhagen: Geol. Surv. Greenland.

Garde, A. A. (compiler) 1989: Geological map of Greenland 1:100000, 64 V.1 N., Fiskefjord. Copenhagen: Geol. Surv. Greenland.

Garde, A. A. 1990: Thermal granulite facies metamorphism with diffuse retrogression in Archaean orthogneisses, Fiskefjord, southern West Greenland. J. metamorphic Geol. $8,663-682$.

Garde, A. A., Larsen, O. \& Nutman, A. P. 1986: Dating of late Archaean crustal mobilisation north of Qugssuk, Godthåbsfjord, southern West Greenland. Rapp. Gronlands geol. Unders. 128, 23-36.

Janardhan, A. S., Newton, R. C. \& Hansen, E. C. 1982: The transformation of amphibolite facies gneiss to charnockite in southern Karnataka and northern Tamil Nadu, India. Contrib. Mineral. Petrol. 79, 130-149.

Leveson, D. J. 1966: Orbicular rocks: a review. Bull. geol. Soc. Am. 77, 409-426.

McGregor, V. R., Friend, C. R. L. \& Nutman, A. P. 1991: The late Archaean mobile belt through Godthåbsfjord, southern West Greenland: a continent-continent collision zone? Bull. geol. Soc. Denmark, this volume.

Nielsen, B. L. 1976: Economic minerals. In Escher, A. \& Watt, W.S. (eds) Geology of Greenland, 18-75. Copenhagen: Geological Survey of Greenland.

Nutman, A. P., Friend, C. R. L., Baadsgaard, H. \& McGregor, V. R. 1989: Evolution and assembly of Archaean gneiss terranes in the Godthåbsfjord region, southern West Greenland: Structural, metamorphic, and isotope evidence. Tectonics 8, 573-589.

Secher, K. 1983: Noritic rocks and associated nickel-coppersulphide occurrences in Sukkertoppen district, central West Greenland. Rapp. Gronlands geol. Unders. 115, 30-34.

Vernon, R. H. 1985: Possible role of superheated magma in the formation of orbicular granitoids. Geology 13, 843-845.

Wells, P. R. A. 1979: Chemical and thermal evolution of Archaean sialic crust, southern West Greenland. J. Petrology 20, 187-226.

Wells, P. R. A. 1980: Thermal models for the magmatic accretion and subsequent metamorphism of continental crust. Earth planet. Sci. Lett. 46, 253-265.

Wiebe, R. A. 1979: Anorthositic dikes, southern Nain complex, Labrador. Am. J. Sci. 279, 394-410.

Wiebe, R. A. 1990: Evidence for unusually feldspathic liquids in the Nain complex, Labrador. Am. Mineral. 75, 1-12. 